UDC 351.81:332.142

http://doi.org/10.21272/mmi.2019.1-14

JEL Classification: F64, N70, N90, 018, R42

Tatsiana Paskannaya,

CEO Simple Kitchen and Bath, USA,

Galyna Shaban,

System manager, Cologne/Bonn Airport, Germany

\title{
INNOVATIONS IN GREEN LOGISTICS IN SMART CITIES: USA AND EU EXPERIENCE
}

Abstract. This article summarizes the arguments within the scientific discussion on the feasibility and applicability of green logistics in Smart Cities. The purpose of the article is to study the features of green logistics and the benefits of implementing its approaches to urban development, based on the analysis of Smart City projects in the USA and the EU, and justifying on this basis the feasibility of taking into account the experience of successful examples in developing urban development strategies around the world. Systematization of literary sources regarding the use of green logistics has shown that it has wide opportunities for introducing both the management of the goods of the companies and the passenger traffic and transport of the city. It is obvious that logistics is closely linked to the structure of the city: transport networks, zones, nodes, that is, with architecture and urban planning, as well as with the environment. Since it is urgent to minimize pollution, increase the efficiency of using logistic resources, optimize the process of making managerial decisions on the use of material, financial and other resources, then there is a need to use the principles of "green logistics» in the city. So, the actuality of this scientific problem solution is caused by the need to find ways to ensure the effectiveness of the proposed measures related to the implementation of urban development projects based on the concept of Smart City, the development of IT, environmental problems. Methodological tools of the research methods were the comparative analysis methods, namely the experience of the EU and the USA in the implementation of green logistics approaches in Smart Cities. The object of research is the leading Smart Cities of the world, as they are an example for other cities to ensure the well-being of their citizens. The paper presents the results of an empirical analysis of the of green logistics issues application in Smart Cities, which has shown that most of them use logistics to movement, storage and distribution of goods, movement and storage of public, passenger transportation, placement of hazardous wastes that affect the ecosystem of the city and against the principles of sustainable development. The research empirically confirms and theoretically proves the efficiency of using green logistics in providing urban development.

Keywords: green logistics, Smart City, GHG emissions, environment, transport, storage, network.

Introduction. Until recently, the main task of logistics managers was to reduce economic costs. Meanwhile, environmental and social costs were ignored for a long period of time.

But some years ago, logistics impact of climate change has sparked a new trend of scientific studies and researches. GHG emissions represented by logistics were discussed during the World Economic Forum. Studies of many types of researchers state that logistics facilities cause for 9 to 10 per cent of the sector's GHG emissions, and the other great part - about two-thirds - is generated by vehicles.

Over the past $10-15$ years, the population and governments of many countries have been focusing on environmental issues, in particular, climate change. This encourages economic subjects to increase investment in facilities reducing their logistics operations to pollution. Thus, the term «green logistics» was formed, which is applied to the carbon footprint of products and services that are consumed.

Analysis of main research and publications. The term «Green Logistics» has transformed over the past 40 years. Originally it focused on the movement of finished goods, transportation, warehousing etc. But now with the growth of environmental awareness "Green Logistics» became a concept of business activity in the ecosystem.

A summary review of the literature in this area has enabled the identification of several advanced definitions.

Cite as: Paskannaya, T., \& Shaban, G. (2019). Innovations in Green Logistics in Smart Cities: USA and EU

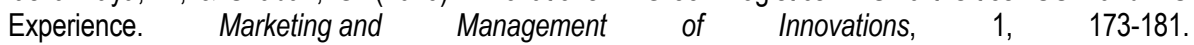
http://doi.org/10.21272/mmi.2019.1-14 
Some scientists (Sbihi et al., 2007) argue that: «Green Logistics is the concept of taking into account environmental and social factors while carrying out logistics activities, whether internally or through $3 \mathrm{PL}$ operators».

Other experts (Thiell et al., 2011) suppose that: «Green logistics consists of all activities related to the eco-efficient management of the forward and reverse flows of products and information between the point of origin and the point of consumption whose purpose is to meet or exceed customer demand».

Modern approaches to the Green logistics concept contain theoretical and applied problems of the companies' development and are considered by the authors (Jedlinski, 2014, Thiell et al., 2011).

Green Logistics concept can be implemented not only by companies but also by local authorities in the city development. To implement the concept of «Green Logistics» in cities required the involvement of local authorities and local businesses. The more urban population learns about environmental problems and methods to solve them, the greater is the pressure on local authorities.

The aim of the article is to study the features of green logistics and the benefits of implementing its approaches to urban development based on the analysis of Smart City projects in the US and the EU and justifying on this basis the feasibility of taking into account the experience of successful examples in developing urban development strategies around the world.

Research results. «Green logistics», concepts and practices around the world. In recent years, there has been a widespread awareness about sustainable development issues among economic players, particularly in terms of environmental protection.

Face to the regulatory and normative requirements governing the logistics sector in terms of respecting the environmental requirements expressed by governments, civil societies and consumers, economic players have recently been investing in the adoption of Green Logistics practices.

Green Logistics concept was established the mid-80s as integrated management of all activities required to move the product along the supply chain to meet the expectations of customers at minimum global cost including also the external costs related to, among others, climate change, air pollution, noise, vibration and accidents.

It is being generally accepted that it is primarily designed to measure and reduce the negative impacts of the overall logistics activities on the ecology, and the parameterization of the effects increases the state of awareness of the consequences of the actions taken, and at the same time gives the possibility of indicating potential areas for optimization (Jedlinski, 2014).

According to (Thiell et al., 2011): «Green logistics system includes green transport; green packaging; green storage; green logistics data collection and management; waste and reverse logistics management». Leading companies in the world call green logistics as a set of environmental and social factors that are used in the logistics process. It becomes a marketing tool for customers who while choosing consumer products and services pay attention to it. The main drivers for using Green Logistics by world companies are presented in Table 1 .

Table 1. Green Logistics various reasons and motivations

\begin{tabular}{|c|c|c|c|}
\hline Managerial & Public & Economical & Marketing \\
\hline $\begin{array}{l}\text { Improving Supply Chain } \\
\text { Efficiency } \\
\text { Improving Investor Relations } \\
\text { Optimizing Logistics Flows } \\
\text { Reducing Logistics Costs } \\
\text { Developing an Alternative } \\
\text { Network }\end{array}$ & $\begin{array}{l}\text { Improving Public Relations } \\
\text { Part Of The Company's } \\
\text { Social And Environmental } \\
\text { Responsibility Agenda } \\
\text { Compliance with } \\
\text { Governmental Regulations }\end{array}$ & $\begin{array}{l}\text { The financial return on } \\
\text { Investment } \\
\text { Reducing fuel bills } \\
\text { Decreasing Risk } \\
\text { The desire to be } \\
\text { considered as a Leader in } \\
\text { Sustainable Development }\end{array}$ & $\begin{array}{l}\text { Ameliorating client } \\
\text { relations } \\
\text { Gaining a } \\
\text { competitive } \\
\text { advantage } \\
\text { satisfying } \\
\text { Customers' } \\
\text { Requirements }\end{array}$ \\
\hline
\end{tabular}

Sources: systematized by the authors on the basis of (Morrocan, 2016) 
Efficient green logistics establish sustainable development in cities. We consider the object of green city logistics is a structured and integrated movement of people, materials and information in an urban area in environmentally friendly mode. According to this, the main spheres of Green city Logistics can be presented in Figure 1.

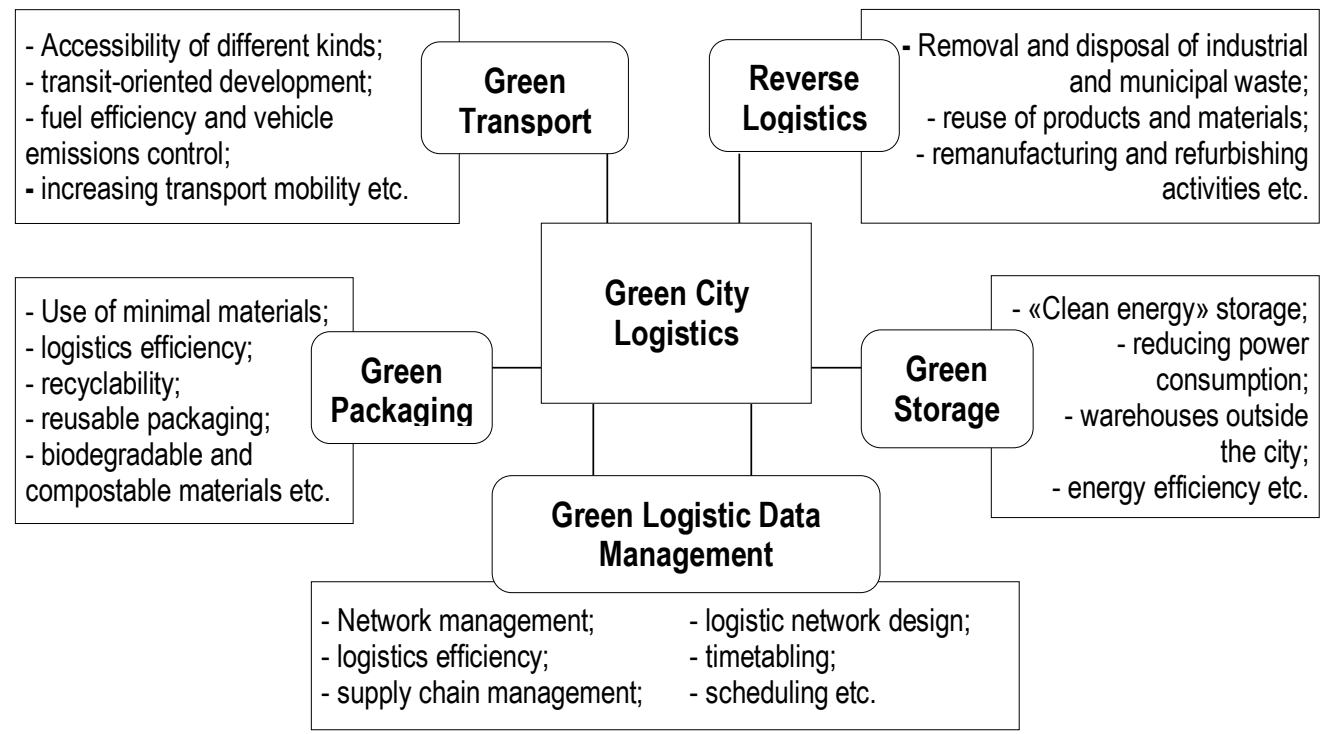

Sources: systematized by the authors.

Figure 1. Green city logistics main spheres

Optimizing logistics in cities is important for the country's economic development, quality of life, and for the accessibility and attractiveness of its urban municipalities. Establishing green logistic principles entails economic, urban and environmental challenges for the city. It consists of several initiatives and projects having a direct and positive impact on $\mathrm{GHG}$ reduction. These measures actually include:

- the organization of freight transport vehicles traffic and parking of within cities,

- the upgrade of public management tools for freight tracks,

- the creation of road transport centres and delivery areas,

- the promotion of modern and suitable city logistic spaces.

According to (Morrocan, 2016): «intensification of merchandise flow is physically reflected in dense urban space. Natural regulation on its own is not likely to absorb, in a durable and sustainable way, the consequences of these flows-notably the nuisances/adverse impacts, which are too often readily pointed out by local collectivities and citizens, alike: road and pedestrian congestion, road safety, sundry nuisances and pollutions (sound, air, and visual), consumption of public spaces».

The system of goods delivery in urban areas affects the economic situation of the city and the quality of its resident's live. Supplying and collecting goods in the central or historical part of the cities negatively affects economic potential, living standards, and the attractiveness of the cities.

Consequently, efficient organization of goods transportation within cities has become important not only for better management of the logistics chain and trade development but also for sustainable city development. (Morrocan, 2016).

Smart Cities Concept and Challenges. According to (Monzon, 2015): «Cities are the main poles of human and economic activity. They hold the potential to create synergies allowing great development 
opportunities to their inhabitants. However, they also generate a wide range of problems that can be difficult to tackle as they grow in size and complexity. Cities are also the places where inequalities are stronger and, if they are not properly managed, their negative effects can surpass the positive ones. Urban areas need to manage their development, supporting economic competitiveness, while enhancing social cohesion, environmental sustainability and increased quality of life of their citizens. With the development of new technological innovations - mainly ICTs - the concept of the «Smart City» emerges as a means to achieve more efficient and sustainable cities» (Juntaek Kim and Uoo Sang Yoo, 2015).

There are several fields of activity which are described in the literature in relation to the term Smart City. We can identify six characteristics (see Table 2), outlined in (Giffinger et al., 2007) as a roof for the further elaboration of smart cities which should incorporate the findings but also allow inclusion of additional factors.

Table 2. Characteristics of a Smart City

\begin{tabular}{|l|l|l|}
\hline \multicolumn{1}{|c|}{ Smart Government } & \multicolumn{1}{|c|}{ Smart Environment } & \multicolumn{1}{c|}{ Smart Mobility } \\
\hline Participation & Green energy, energy efficiency & Mixed-modal access \\
\hline $\begin{array}{l}\text { Transparency and information } \\
\text { accessibility (open data) }\end{array}$ & Smart building and building renovation & Traffic management \\
\hline Public and social services & Resource management & Public transport \\
\hline ICT and e-Gov & Environmental protection & \multicolumn{1}{c|}{ Smart People } \\
\hline \multicolumn{1}{|c|}{ Smart Economy } & \multicolumn{1}{|c|}{ Smart Living } \\
\hline Entrepreneurship and innovation & $\begin{array}{l}\text { Community building and urban life } \\
\text { management }\end{array}$ & Save and healthy \\
\hline Productivity & Inclusive society & Culture, leisure and tourism \\
\hline $\begin{array}{l}\text { Local and global } \\
\text { interconnectedness }\end{array}$ & 21-st century education & Technology accessibility \\
\hline The flexibility of the labour market & Creativity & Security \\
\hline
\end{tabular}

Sources: compiled by the authors on the basis of (Giffinger et al., 2007; Monzon, 2015)

The most famous and most successful Smart Cities in the world are Amsterdam, Barcelona, Beijing, Columbus, Dubai, Helsinki, London, Madrid, Paris, Singapore, Stockholm and others.

Green Logistics practice in Smart City. The main indicators of Green logistics environmental performance are energy consumption, the number of tons of logistics platforms and transport $\mathrm{CO} 2$ emissions, the number of tons-kilometres, the levels of traffic congestion.

The carbon footprint of logistic activity is a major problem for Green Logistics measures. Among the main measures are the following: the use of more environmentally friendly modes of transport, including electric vehicles, environmental education. Measures aimed at reducing the use of packaging materials or replacing them with more environmentally friendly ones that can be reused or disposed of are considered to be effective. Additionally, measures are proposed to optimize delivery routes, public transport routes, etc.

Reducing the carbon footprint of the logistics chain is a major concern for green logistics practices. The related emerging trends involve several aspects, presented in (Morrocan, 2016): «1) implementation of logistics platforms and hubs for large volumes to consolidate the flows of goods; 2) pooling and development of multimodal transport combining road, railways, air and sea to reduce GHG emissions and roads congestion; 3) selection of environment-friendly means of transportation and logistics similarly to the use of vehicle fleets with low $\mathrm{CO} 2$ emissions or the use of hybrid propulsion technologies; 4) development of environmentally efficient infrastructures and logistics facilities; 5) reconfiguring the logistics network for more efficiency by favouring maximized use of transportation capacities and minimizing the movement of goods, notably by making relevant choices in terms of storage locations; 6 ) 
use of business software packages and NTICs which contribute to the optimization of everyday transport logistics operations (TMS) and storage (WMS) and therefore reducing GHG emissions; 7) eco-driving Training could lead to substantial energy gains by saving energy; 8) reducing packaging and increasing the rate of product recyclability are also concrete steps to reducing the environmental footprint of goods; 9) city logistics where there is room for a lot of improvement, such as the collaborative distribution among several companies of transport, storage, infrastructure and reverse logistics which include the recycling of products and packages and the regulation and organization of the movement of freight transport vehicles in urban areas».

Smart Cities developing is a world tendency, caused to solve common problems of humanity in different countries, is closely connected with ICT-solutions. Green logistics is a tool for solving these problems and providing better perspectives for future development of the cities. IT easily can be seen in through Sustainable Development Goals, Goal 11 Sustainable cities and communities means: «By 2030, provide access to safe, affordable, accessible and sustainable transport systems for all, improving road safety, notably by expanding public transport, reduce the adverse per capita environmental impact of cities, including by paying special attention to air quality and municipal and other waste management» and so on (About, 2015).

Green logistics in Smart City practices in the USA and EU. According to (Duffy, 2018) about 12 of the world's 50 smartest cities are American. Among them are New York City, Boston, San Francisco, Chicago, Seattle, Columbus and others. It should be noted that the City of Columbus is a winner of Smart City Challenge in 2016 - competition among mid-sized cities in the USA in developing ideas for an integrated, first-of-its-kind smart transportation system that would use data, applications, and technology to help people and goods move more quickly, cheaply, and efficiently. The City of Columbus won $\$ 40$ million with the proposition of a comprehensive, integrated plan addressing challenges in residential, commercial, freight, and downtown districts using a number of new technologies, including connected infrastructure, electric vehicle charging infrastructure, an integrated data platform, autonomous vehicles, etc (The Winner, 2018). As you can see the creators of the smart city concept used green logistics methods and techniques to solve city problems.

Let's consider some examples of the US Smart Cities (table 3) and the EU Smart Cities (table 4) more detailed. Most of them are closely connected with solving transportation problems - the main logistic sphere, or solving problems which are caused by transport.

Table 3. US Smart Cities, implementing Green Logistics approaches

\begin{tabular}{|l|l|}
\hline Smart City & \multicolumn{1}{|c|}{ Green Logistics approaches } \\
\hline \multicolumn{1}{|c|}{$\begin{array}{l}\text { Pittsburgh, } \\
\text { Pennsylvania }\end{array}$} & $\begin{array}{l}\text { Fighting a decreasing population, the city of Pittsburgh has proposals in place for } \\
\text { reinventing its infrastructure. With IBM Smarter Cities, they have worked on } \\
\text { MOVEPGH, their transportation improvement plan, which will make the city more bike } \\
\text { and pedestrian friendly. Pittsburgh also plans to revitalize the Almono steel site with a } \\
\text { microgrid of solar and geothermal energy and make the city greener with LED } \\
\text { streetlights and electric vehicle charging stations. Once an industrial powerhouse, } \\
\text { Pittsburgh looks poised for a comeback through smart technology. }\end{array}$ \\
\hline Austin, Texas & $\begin{array}{l}\text { A city on the rise, Austin's city council has set its sights on becoming a smart city. On } \\
\text { their dedicated smart city page on the website, they describe their transportation } \\
\text { plans, which involves automated and connected vehicles, intelligent sensors, open } \\
\text { data, and real-time traveller information. They have formed many regional } \\
\text { partnerships, including with the Texas Department of Transportation, the University of } \\
\text { Texas, and Austin Energy. }\end{array}$ \\
\hline
\end{tabular}


Continue Table 3

\begin{tabular}{|c|c|}
\hline 1 & 2 \\
\hline $\begin{array}{l}\text { San Francisco, } \\
\text { California }\end{array}$ & $\begin{array}{l}\text { San Francisco has an innovative and creative atmosphere that has led to many new } \\
\text { smart technologies being implemented in the city. Through smarter pricing for } \\
\text { parking, we help to achieve the right level of parking availability by periodically } \\
\text { adjusting meter and garage to match demand. Known as «demand-responsive } \\
\text { pricing», this encourages people to park in underutilized blocks and garages, helping } \\
\text { to open up spaces in busy areas and at busy times. From its many «green» initiatives } \\
\text { to its smart parking system, San Francisco earns its reputation of being an avant- } \\
\text { garde city. }\end{array}$ \\
\hline $\begin{array}{l}\text { New York City, } \\
\text { New York }\end{array}$ & $\begin{array}{l}\text { Ranked the } 2 \text { nd leading smart city globally, this smart city has already incorporated } \\
\text { many transportation innovations. The NYC sanitation department is the largest in the } \\
\text { world, collecting more than } 10,500 \text { tons of trash per day. Picking up garbage from the } \\
\text { thousands of trash cans and recycling bins can be quite a logistical challenge: } \\
\text { garbage bins can overflow if they are left unattended but picking up garbage too } \\
\text { frequently is a waste of fuel and labour. These smart waste management systems not } \\
\text { only reduce the frequency of garbage collection, but they also allow it to be scheduled } \\
\text { more effectively. The BigBelly improves trash collection efficiency by } 50 \% \text { to } 80 \% \text { and } \\
\text { also contributes to emissions control by reducing the time spent by garbage trucks on } \\
\text { the road. }\end{array}$ \\
\hline
\end{tabular}

Sources: systematized by the authors on the basis of (Tobias, (2018); Top 10, 2017; DemandResponsive Parking, 2017)

Table 4. EU Smart Cities, implementing Green Logistics approaches

\begin{tabular}{|l|l|}
\hline \multicolumn{1}{|c|}{ Smart City } & \multicolumn{1}{c|}{ Green Logistics approaches } \\
\hline \multicolumn{1}{|c|}{$\mathbf{1}$} & \multicolumn{1}{c|}{ 2 } \\
Kingdom) & $\begin{array}{l}\text { (United } \\
\text { using wireless technologies. All the details of this innovation are hidden under the } \\
\text { roadway. The project is being implemented under the patronage of the state } \\
\text { organization Highways England and its goal is to increase in the distance of passenger } \\
\text { travel and cargo electric cars. }\end{array}$ \\
\hline $\begin{array}{l}\text { Copenhagen, } \\
\text { Malmo } \\
\text { (Denmark) }\end{array}$ & $\begin{array}{l}\text { Copenhagen is famous for a Guinness World Record when more than 200 electric cars } \\
\text { met on the bridge. The city has the Climate Action Plan, the Bicycle Strategy and the } \\
\text { Strategy for Urban Life. The city government pays much attention to reductions in } \\
\text { carbon emissions. For this reason, it provides a decreasing number of individual trips } \\
\text { by car, an increasing number of trips by foot, bike or public transport, etc. }\end{array}$ \\
\hline $\begin{array}{l}\text { Vienna } \\
\text { (Austria) }\end{array}$ & $\begin{array}{l}\text { The city has become the fifth in the green list of EU Smart-Cities. To reduce transport- } \\
\text { related emissions, which account for one-third of the city's total CO2 emissions, Vienna } \\
\text { has encouraged the use of public transport by introducing shorter bus-service intervals, } \\
\text { all-night bus services and an extensive network of cycle routes. All of Vienna's buses } \\
\text { operate using liquefied petroleum gas (LPG) engines, which have lower nitrogen oxide } \\
\text { and carbon monoxide emissions than diesel engines. }\end{array}$ \\
\hline
\end{tabular}


Continue Table 4

\begin{tabular}{|l|l|}
\hline \multicolumn{1}{|c|}{1} & \multicolumn{1}{|c|}{2} \\
\hline $\begin{array}{l}\text { Stockholm } \\
\text { (Sweden) }\end{array}$ & $\begin{array}{l}\text { Stockholm ranks first in the transport category. A large proportion of people walk or } \\
\text { cycle to work, and the cycle network is well developed. Stockholm has the highest } \\
\text { percentage of clean vehicles in Europe, and } 75 \% \text { of the city's public transport network } \\
\text { runs on renewable energy. To reduce emissions, the Clean Vehicles in Stockholm } \\
\text { initiative, which promotes hybrid and biofuel-powered vehicles, has the objective of } \\
\text { reaching a market breakthrough level of } 5 \% \text { for clean vehicles. The initiative's goals } \\
\text { are that by the end of } 2010 \text { all of the municipality's own vehicles will be clean and that } \\
35 \% \text { of new-car sales will be of clean vehicles. }\end{array}$ \\
\hline
\end{tabular}

Sources: systematized by the authors on the basis of (European, 2009)

Green logistics in a smart city is not considered only as a way to solve environmental or economic problems. This is a toolkit of urban management aimed at improving the quality of life of local residents, whose indicators are economic, social and environmental benefits.

These are, for example, an increase in the well-being of citizens, an improvement in the quality of water, air, green zones), stability and prospects for life, economic growth, increased availability of IT, mobile devices, etc.

Conclusions. The best strategy for the city is a future that will be smart and green. If citizens have the choice, they want to live in smart green cities, where the quality of life increases and the state of the environment improves. We face the awkward truth about anthropogenic climate change, due to how we live and do business, using our limited resources, without paying attention to the consequences.

The transformation into the Smart-City involves the widespread use of information and communication technologies to connect people and things (cars, cars, devices and sensors) in order to be smarter on a global scale. Green logistics in Smart city means that companies and authorities must incorporate sustainability management into their corporate strategy by developing, manufacturing, marketing, and recycling environmentally friendly products and services.

Each economy, company, organization and government must become smart and green and minimize its destructive impact on the natural environment. It is important for public authorities, entrepreneurs and service providers to understand the innovations and challenges that people want to see in smart cities and communities and to pay more attention to the human and social implications of their initiatives.

In this case, optimization of urban logistics becomes vital for the development of the city, accessibility and attractiveness, as well as for improving the quality of population lives. In fact, the directions for introducing green logistics approaches into the Smart City concept are as follows:

- urban planning, which means an increasing number of public transport users and reducing urban workload,

- combating traffic jams, etc.;

- environmental contribution, which is to reduce emissions of pollutants and noise arising from freight traffic in the city, recycling and reusing materials;

- economic interest, which is to reduce the cost of transportation, storage, packaging, etc.

What are the benefits?

1. Optimized logistics systems aimed to improve the organization of goods and residents movement in cities.

2. High-performance logistics - managing the transportation of goods within the city, creating a corresponding logistics infrastructure.

3. Well-controlled development of social, environmental and economic indicators, aimed at holding green urban logistics in the management at the territory level. 
Authors Contributions: Authors have an equal contribution for preparing the manuscript. Conceptualization, P. T.; methodological issue, P. T.; analysis and investigation, P. T., S. G.; resources S. G., writing an original draft, P. T.; revision, P. T., S. G.; formatting, S. G.

\section{References}

About the Sustainable Development Goals (2015). Retrieved from https://www.un.org/sustainabledevelopment/sustainabledevelopment-goals/

Albino V. (2012). Green Cities into Practice / V. Albino, R.M. Dangelico. The Economy of Green Cities: A World Compendium on the Green Urban Economy. - Dordrecht: Netherlands: Springer Science Business Media B.V.

Bollier, D. (1998). How Smart Growth Can Stop Sprawl: A Fledgling Citizen Movement Expands. Washington: D.C. Essential Books/Sprawl Watch Clearinghouse.

Dekker, R., Bloemhof, J., \& Mallidis, I. (2012). Operations Research for green logistics-An overview of aspects, issues, contributions and challenges. European Journal of Operational Research, 219(3), 671-679.

Demand-Responsive Parking (2017). Retrieved from https://www.sfmta.com/demand-responsive-parking

Duffy, R. (2018) Twelve of the top 50 smart cities in the world are in the U.S., according to a new report. Retrieved from https://statescoop.com/twelve-of-the-top-50-smart-cities-in-the-world-are-in-the-u-s-according-to-new-report

$\begin{array}{lllll}\text { European Green } & \text { City Index } & \text { (2009). } & \text { Retrieved }\end{array}$ https://www.siemens.com/entry/cc/features/greencityindex_international/all/en/pdf/report_en.pdf

Giffinger, R., Fertcher, C., Kramar, H. and others. Smart cities - Ranking of European medium-sized cities. Final report of a research project (2007) Centre of Regional Science, Vienna UT. Retrieved from http://www.smartcities.eu/download/smart_cities_final_report.pdf

Jedlinski, M. (2014) The position of green logistics in sustainable development of a smart green city. Procedia - Social and Behavioral Sciences, Volume 151, 102-111. https://doi.org/10.1016/j.sbspro.2014.10.011 Retrieved from https://www.sciencedirect.com/science/article/pii/S1877042814054536

Juntaek Kim and Uoo Sang Yoo (2015) New Sustainable Urban Design Strategies for the Beijing Region's Most Extensive Green, Compact City: Case Study of Bohai Innovation City. Proceedings of the 8th Conf. Int. Forum Urban., D020, doi:10.3390/ifouD020 https://sciforum.net/paper/view/conference/2747

Lai, K. H., \& Wong, C. W. (2012). Green logistics management and performance: Some empirical evidence from Chinese manufacturing exporters. Omega, 40(3), 267-282.

Lyulyov, O., Chortok, Y., Pimonenko, T., \& Borovik, O. (2015). Ecological and economic evaluation of transport system functioning according to the territory sustainable development. International Journal of Ecology and Development, 30(3), 1-10.

Luciano, M. (2015) Top 10 Smartest Cities in The World. Retrieved from https://www.ecnmag.com/blog/2017/11/top-10smartest-cities-world

McKinnon, A. (2010). Green logistics: the carbon agenda. Electronic Scientific Journal of Logistics, 6(1).

Monzon, A. (2015) Smart Cities Concept and Challenges: Bases for the Assessment of Smart City Projects // Springer International Publishing Switzerland 2015 M. Helfert et al. (Eds.): Smartgreens 2015 and Vehits 2015, CCIS 579, 17-31. DOI: 10.1007/978-3-319-27753-0_2

Morrocan green logistics (2016) Retrieved from http://www.amdl.gov.ma/amd//wp-content/uploads/2016/11/Ouvrage-MGLAnglais.pdf

Murphy, P. R., \& Poist, R. F. (2000). Green logistics strategies: an analysis of usage patterns. Transportation journal, 5-16.

Piecyk, M., Browne, M., Whiteing, A., \& McKinnon, A. (Eds.). (2015). Green logistics: Improving the environmental sustainability of logistics. Kogan Page Publishers. 350.

Rodrigue, J. P., Slack, B., \& Comtois, C. (2008). Green logistics. In Handbook of logistics and supply-chain management, 339-

Sbihi, A., Eglese, R. W. (2007). The Relationship between Vehicle Routing Scheduling and Green Logistics. Retrieved from https://hal.archives-ouvertes.fr/hal-00644133/document

The Winner: Columbus, Ohio (2018). Retrieved from https://www.transportation.gov/smartcity/winner

Thiell, M., Zuluaga, J. P. S., Montanez, J. P. M. \& Hoof, B. (2011). Logistique verte : Pratiques globales et leur mise en oeuvre dans les marchés émergents. Retrieved from http: //www.irma-international.org/viewtitle/53258/

Tobias, M. (2018) How New York is Becoming a Smart City. Retrieved from https://www.ny-engineers.com/blog/how-new-yorkis-becoming-a-smart-city

Top 10 Smart Cities in the U.S. (2017) Retrieved from https://www.routematch.com/top-10-smart-cities-us/ 
T. Пасканная, CEO «Simple Kitchen and Bath» (США);

Г. Шабан, системний менеджер, Аеропорт Кельн-Бонн (Німеччина).

Інновації зеленої логістики в «розумних» містах: досвід США та ЄС

Ця стаття узагальнює аргументи в межах наукової дискусії з питання можливості та доцільності застосування зеленої логістики в "розумних» містах. Метою статті є вивчення особливостей зеленої логістики та переваг реалізаціїії підходів до містобудування на основі аналізу проектів "розумних» міст у США та ЄС і обгрунтування на цій основі доцільності врахування досвіду успішних прикладів розробки стратегій розвитку міст у світі. Систематизація літературних джерел щодо сфрер використання зеленої логістики засвідчила, що вона має широкі можливості впровадження як в управлінні товарорухом компаній, так і пасажиропотоків і транспорту міста. Очевидним є те, що логістика тісно пов'язана із структурою міста: транспортними мережами зонами, вузлами, тобто з архітектурою та містобудуванням, а також з екологією. Оскільки нагальною $\epsilon$ необхідність мінімізації забруднення, підвищення ефективності використання логістичних ресурсів, оптимізації процесу прийняття управлінських рішень щодо використання матеріальних, фрінансових та інших ресурсів, то виникає необхідність використання принципів «зеленої логістики» в місті. Отже, актуальність вирішення даної наукової проблеми обумовлена необхідністю пошуку засобів забезпечення ефективності пропонованих заходів, пов'язаних із впровадженням проектів розвитку міст на основі концепції "розумного» міста, розвитком IT, загостренням проблем навколишнього середовища. Методичним інструментарієм проведеного дослідження стали методи порівняльного аналізу, а саме досвіду ЄС і США у впровадженні зеленої логістики в «розумних» містах. Об'єктом дослідження обрані провідні «розумні» міста світу, оскільки саме вони є прикладом для інших міст у забезпеченні добробуту своїх мешканців. В статті представлено результати аналізу сфер застосування засобів зеленої логістики в "розумних» містах, який засвідчив, що більшість з них використовують логістичні підходи для переміщення, зберігання, розподілу вантажів, пересування $і$ зберігання суспільного, легкового транспорту, розміщення небезпечних відходів, що негативно впливають на екосистему міста та суперечать принципам стійкого розвитку. Дослідження емпірично підтверджує та теоретично доводить ефрективність використання зеленої логістики у забезпеченні розвитку міст.

Ключові слова: зелена логістика, "розумне» місто, викиди парникових газів, навколишнє середовище, транспорт, зберігання, мережа.

Manuscript received: 28/11/2018

(c) The author(s) 2019. This article is published with open access at Sumy State University. 